\title{
Chromosomal Microarray Analysis for the Prenatal Diagnosis in Fetuses with Nasal Bone Hypoplasia: A Retrospective Cohort Study
}

\author{
Hailong Huang $\mathbb{D}^{1, *}$ \\ Meiying Cai $\mathbb{D}^{1}, *$ \\ Wei Ma ${ }^{1,2}$ \\ $\mathrm{Na} \operatorname{Lin}^{\prime}$ \\ Liangpu Xu (1) ${ }^{\prime}$
}

'Fujian Maternity and Child Health Hospital, Affiliated Hospital of Fujian Medical University, Fujian Key Laboratory for Prenatal Diagnosis and Birth Defect, Fuzhou City, Fujian Province, 35000I People's Republic of China; ${ }^{2}$ School of Clinical Medicine, Fujian Medical University, Fuzhou City, Fujian Province, 350122, People's Republic of China

*These authors contributed equally to this work
Correspondence: Liangpu Xu; $\mathrm{Na}$ Lin Fujian Maternity and Child Health Hospital, Affiliated Hospital of Fujian Medical University, Fujian Key Laboratory for Prenatal Diagnosis and Birth Defect, No. 18 Daoshan Road, Gulou District, Fuzhou City, Fujian Province, 35000I, People's Republic of China Tel +86-059l-87554929

Email Xiliangpu@fjmu.edu.cn; 846519465@qq.com
Background: Previous studies have shown a strong correlation between fetal nasal bone hypoplasia and chromosomal anomaly; however, there is little knowledge on the associations of fetal nasal bone hypoplasia with chromosomal microdeletions and microduplications until now. Chromosomal microarray analysis (CMA) is a high-resolution molecular genetic tool that is effective to detect submicroscopic anomalies including chromosomal microdeletions and microduplications that cannot be detected by karyotyping. This study aimed to examine the performance of CMA for the prenatal diagnosis of nasal bone hypoplasia in the second and third trimesters.

Subjects and Methods: A total of 84 pregnant women in the second and third trimesters with fetal nasal bone hypoplasia, as revealed by ultrasound examinations, were enrolled, and all women underwent karyotyping and CMA with the Affymetrix CytoScan 750K GeneChip Platform. The subjects included 32 cases with fetal nasal bone hypoplasia alone and 52 cases with fetal nasal bone hypoplasia combined with other ultrasound abnormalities, and the prevalence of genomic abnormality was compared between these two groups.

Results: Karyotyping detected 21 cases of chromosomal anomaly in the 84 study subjects (21/ 84, 25\%), including trisomy 21 (14 cases), trisomy 18 (3 cases), 46, del (4)(p16) karyotype (2 cases), 47, XYY syndrome (1 case) and 46, XY, del (5) (p15) karyotype (1 case). CMA detected additional four fetuses with pathogenic copy number variations (CNVs) and six fetuses with uncertain clinical significance (VOUS). No significant difference was detected in the prevalence of genomic abnormality in fetuses with nasal bone hypoplasia alone and in combination with other ultrasound abnormalities $\left(13 / 32\right.$ vs $\left.18 / 52 ; \chi^{2}=0.31, P>0.05\right)$. The pregnancy was terminated in 21 fetuses detected with chromosomal abnormality and 4 fetuses detected with pathogenic CNVs. Among the other six fetuses detected with VOUS, the parents chose to continue the pregnancy, and the newborns all had normal clinical phenotypes.

Conclusion: In addition to chromosomal abnormalities identified in 21 fetuses by karyotyping, CMA detected additional 10 fetuses with abnormal CNVs $(10 / 84,11.9 \%)$ in the study population. CMA is a promising powerful tool for prenatal diagnosis that may provide valuable data for the accurate assessment of fetal prognosis and the decision of pregnancy continuation during the prenatal clinical counseling.

Keywords: nasal bone hypoplasia, chromosomal microarray analysis, prenatal diagnosis, copy number variation

\section{Introduction}

Ultrasonography is an important part of prenatal screening. ${ }^{1}$ Currently, the common genetic ultrasound soft markers include nuchal translucency thickening, nasal bone 
hypoplasia and shortening of fetal long bones, ${ }^{2}$ and these soft markers show diverse values in prediction of fetal abnormalities. $^{3}$

Fetal nasal bone hypoplasia is defined as absence or dysplasia of the nasal bone on the mid-sagittal plane in the second trimester as detected by ultrasonography. ${ }^{4}$ Previous studies have shown a strong correlation between fetal nasal bone hypoplasia and chromosomal anomaly, ${ }^{5-7}$ and the highest incidence of nasal bone hypoplasia is detected in fetuses with aneuploidy, ${ }^{8-10}$ notably in Down syndrome (trisomy 21). ${ }^{5,11,12}$ However, there is little knowledge on the associations of fetal nasal bone hypoplasia with chromosomal microdeletions and microduplications until now. ${ }^{13,14}$

Chromosomal microarray analysis (CMA) is a highresolution molecular genetic tool that is effective to detect chromosomal microdeletions and microduplications that cannot be detected by karyotyping. This retrospective cohort study aimed to examine the performance of CMA for the prenatal diagnosis of nasal bone hypoplasia in the second and third trimesters.

\section{Subjects and Methods Subjects}

We collected 84 fetuses diagnosed with fetal nasal bone hypoplasia, as revealed by ultrasound examinations at the Center of Prenatal Diagnosis, Fujian Maternity and Child Health Hospital (Fuzhou, China) during the period from December 2016 through December 2018. The pregnant women had ages of 20 to 41 years, and had gestational ages of 18 to 36 weeks. All pregnant women underwent karyotyping and CMA with amniotic fluid and umbilical blood samples. Among the 84 prenatal samples collected, there were 53 amniotic fluid samples and 31 umbilical blood samples. The subjects included 32 cases with fetal nasal bone hypoplasia alone and 52 cases with fetal nasal bone hypoplasia combined with other ultrasound abnormalities. The subjects' medical records were retrospectively reviewed.

\section{Karyotyping}

Chromosome karyotyping analysis was routinely performed as described previously. ${ }^{15}$ Briefly, amniotic fluid and umbilical cord blood samples were collected, cultured, harvested and subjected to G-band karyotype analysis, with additional $\mathrm{C}$ - and N-band karyotyping performed if required. Amniocentesis was performed at 18 to 24 weeks of gestation, while cordocentesis was performed after 24 weeks of gestation. Karyotyping was done on a Leica GSL-120 automatic slide scanning system (Leica Biosystems Richmond, Inc.; Richmond, IL, USA). Each sample was detected for 40 karyotypes, with 5 used for banding, and additional detections were performed if required.

\section{CMA}

Approximately $10 \mathrm{~mL}$ of amniotic fluid and umbilical cord blood specimens were collected, centrifuged and the sediment was collected. Genomic DNA was isolated from amniotic fluid cells using the QIAamp DNA Blood Mini Kit (Qiagen; Hilden, Germany). All CMA analyses were performed using the Affymetrix CytoScan $750 \mathrm{~K}$ GeneChip Platform (Affymetrix, Santa Clara, CA, USA) with copy number variation (CNV) and single nucleotide polymorphism (SNP) probes following the manufacturer's instructions. All CMA data were processed with the software Chromosome Analysis Suite version 3.2 (Affymetrix; Santa Clara, CA, USA), and the analysis was capable of detecting CNVs with clinically relevant genes and genome-wide backbone resolution of greater than $100 \mathrm{~kb}$. The CNVs were interpreted using public databases, including the database of genomic variants (http://dgv.tcag.ca/dgv/app/home), the DECIPHER database (https://decipher.sanger.ac.uk/), Online Mendelian Inheritance in Man (https://www.omim.org/), International Standards for Cytogenomic Arrays (ISCA) Consortium (http://www.iscaconsortium.org/) and the Cytogenomics Array Group CNV Database (CAGdb database; http://www.cagdb.org/), as well as National Center for Biotechnology Information (NCBI). All CNVs detected were classified as pathogenic, benign or variants of uncertain clinical significance (VOUS) according to the American College of Medical Genetics standards and guidelines. ${ }^{16}$ In addition, the peripheral blood was sampled from the parents of fetuses with VOUS for CMA analysis, and the type of CNVs was validated by means of CMA and pedigree analysis.

\section{Ethical Consideration}

This study was approved by the Ethics Review Committee of Fujian Maternity and Child Health Hospital. All participants were informed of the purpose, experimental procedures and potential risks of the study, and signed an informed consent. All experiments were performed in accordance with the Declaration of Helsinki and National 
Regulations for Ethics of Biological Medical Sciences on Human Studies released by Ministry of Health, China.

\section{Statistical Analysis}

All statistical analyses were performed using the statistical software SPSS version 22.0 (SPSS, Inc.; Chicago, IL, USA). Differences of proportions were tested for statistical significance with chi-square test or Fisher's exact test, and a $P$ value of $<0.05$ was considered statistically significant.

\section{Results}

\section{Chromosome Karyotyping}

There were 84 prenatal samples with karyotyping analysis, including 53 amniotic fluid specimens and 31 cord blood specimens. G-band karyotype analysis detected 21 cases of chromosomal anomaly in the 84 study subjects (21/84, $25 \%$ ), and fetal chromosomal anomaly included trisomy 21 (14 cases), trisomy 18 (3 cases), 46, del (4)(p16) karyotype (2 cases), 47, XYY syndrome (1 case) and 46, $\mathrm{XY}$, del (5) (p15) karyotype (1 case). Table 1 shows the karyotype, ultrasound findings and pregnant outcomes in fetuses with chromosomal anomaly.

\section{CNVs Detected by CMA}

All fetuses in our study were further tested for chromosomal anomaly using CMA. In addition to the 21 fetuses identified with chromosomal anomaly described above, CMA detected additional CNVs in 10 fetuses, including 4 fetuses with pathogenic CNVs and 6 fetuses with VOUS. The pathogenic CNVs included 15q13.2q13.3 microdeletion, $16 \mathrm{p} 12.2$ microdeletion, $17 \mathrm{p} 12$ microdeletion and $15 \mathrm{q} 24.1 \mathrm{q} 24.2$ microdeletion, and VOUS included 15q13.3 microduplication, 16p13.13p13.12 microduplication, 2p22.3 microduplication, $15 \mathrm{q} 11.2$ microdeletion, Xq21.33 microduplication and 15q26.1 microdeletion (Table 2).

There was no significant difference was detected in the prevalence of genomic abnormality in fetuses with nasal bone hypoplasia alone and in combination with other ultrasound abnormalities $\left(13 / 32\right.$ vs $\left.18 / 52 ; \chi^{2}=0.31, P>0.05\right)$ (Table 3).

\section{Pregnant Outcomes}

All 84 fetuses were successfully followed up. The pregnancy was terminated in 21 fetuses detected with chromosomal abnormality and 4 fetuses detected with pathogenic CNVs. Among the other six fetuses detected with VOUS, five cases were had pedigree analysis, the parents chose to continue the pregnancy, and the newborns all had normal clinical phenotypes (Tables 1 and 2).

\section{Discussion}

The genetic etiology of fetal nasal bone hypoplasia has been extensively investigated, ${ }^{17}$ and a close association has been identified between fetal nasal bone hypoplasia and chromosomal abnormality, ${ }^{5-7}$ notably with aneuploidy. ${ }^{8-10}$ In this study, we detected trisomy 21 in 14 cases, trisomy 18 in 3 cases and 47, XYY syndrome in one case among the 84 fetuses with nasal bone hypoplasia, and the prevalence of aneuploidy was $21.43 \%$ in the study subjects. In a previous study recruiting 239 fetuses at gestational ages of 15 to 20 weeks, absence of a nasal bone was detected in $37 \%$ of fetuses with trisomy 21 and $0.5 \%$ of normal fetuses, yielding a likelihood ratio of 83 , and the findings suggested that absence of a nasal bone is the most sensitive ultrasound soft marker for trisomy $21 .{ }^{18}$ Sonek and colleagues reported a $1 \%$ prevalence of absent nasal bones in normal fetuses and $37 \%$ prevalence in fetuses with trisomy 21 in the second trimester, yielding a positive likelihood ratio of 41 and negative likelihood ratio of 0.64 , and they concluded that absence of a nasal bone shows a high predictive value for trisomy $21 .{ }^{19}$ In the current study, we detected a lower prevalence of aneuploidy in the subjects as compared to previous reports. In our center, if the pregnant women harboring aneuploidy fetuses present a high risk of trisomy 21 as detected by the blood testing or non-invasive prenatal test (NIPT) in the first trimester, and they may lose the timing to directly receive prenatal diagnosis by amniocentesis without ultrasound screening. If the fetus is definitively diagnosed with aneuploidy, induction of labor is given, and the diagnosis of aneuploidy fetuses with absence of a nasal bone may be missed. Therefore, the prevalence of aneuploidy detected in the fetuses with nasal bone hypoplasia was lower in this study than previous reports.

CMA has a high resolution to detect microdeletions and microduplications, ${ }^{20-22}$ which supplements the shortcomings of conventional G-band karyotyping in misdiagnosis of small chromosomal segments. ${ }^{23}$ In this study, CMA detected microdeletions and microduplications in 10 fetuses with nasal bone hypoplasia, which increased the detection of genomic abnormalities by $11.9 \%$ as compared to G-banding karyotype analysis. We detected no significant difference in the prevalence of genomic abnormality in fetuses with nasal bone hypoplasia alone and in combination with other ultrasound abnormalities 
Table I Chromosome Karyotyping Detects Abnormal Karyotypes in 2 I Fetuses with Nasal Bone Hypoplasia

\begin{tabular}{|c|c|c|c|c|}
\hline $\begin{array}{l}\text { Fetus } \\
\text { No. }\end{array}$ & $\begin{array}{l}\text { Invasive } \\
\text { Procedure }\end{array}$ & $\begin{array}{c}\text { Chromosome } \\
\text { Karyotype }\end{array}$ & Ultrasound Findings & $\begin{array}{l}\text { Pregnant } \\
\text { Outcome }\end{array}$ \\
\hline I & AS & Trisomy 21 & Fetal nasal bone hypoplasia & $\begin{array}{c}\text { Induction of } \\
\text { labor }\end{array}$ \\
\hline 2 & AS & Trisomy 21 & Fetal nasal bone hypoplasia & $\begin{array}{c}\text { Induction of } \\
\text { labor }\end{array}$ \\
\hline 3 & AS & Trisomy 21 & Fetal nasal bone hypoplasia & $\begin{array}{c}\text { Induction of } \\
\text { labor }\end{array}$ \\
\hline 4 & CS & Trisomy 21 & Fetal nasal bone hypoplasia & $\begin{array}{c}\text { Induction of } \\
\text { labor }\end{array}$ \\
\hline 5 & AS & Trisomy 21 & Fetal nasal bone hypoplasia and nuchal translucency thickening & $\begin{array}{c}\text { Induction of } \\
\text { labor }\end{array}$ \\
\hline 6 & AS & Trisomy 21 & Fetal nasal bone hypoplasia and nuchal translucency thickening & $\begin{array}{c}\text { Induction of } \\
\text { labor }\end{array}$ \\
\hline 7 & AS & Trisomy 21 & Fetal nasal bone hypoplasia and nuchal translucency thickening & $\begin{array}{c}\text { Induction of } \\
\text { labor }\end{array}$ \\
\hline 8 & AS & Trisomy 21 & Fetal nasal bone hypoplasia and nuchal translucency thickening & $\begin{array}{c}\text { Induction of } \\
\text { labor }\end{array}$ \\
\hline 9 & AS & Trisomy 21 & Fetal nasal bone hypoplasia and cysts of the choroid plexus of bilateral ventricles & $\begin{array}{c}\text { Induction of } \\
\text { labor }\end{array}$ \\
\hline 10 & AS & Trisomy 21 & Fetal nasal bone hypoplasia, echogenic bowel and hyperechogenic foci in the left ventricle & $\begin{array}{c}\text { Induction of } \\
\text { labor }\end{array}$ \\
\hline 11 & AS & Trisomy 21 & Fetal nasal bone hypoplasia, echogenic bilateral renal parenchyma, and echogenic hepatic parenchyma & $\begin{array}{c}\text { Induction of } \\
\text { labor }\end{array}$ \\
\hline 12 & AS & Trisomy 21 & Fetal nasal bone hypoplasia, nuchal fold thickening, and aberrant right subclavicular artery & $\begin{array}{c}\text { Induction of } \\
\text { labor }\end{array}$ \\
\hline 13 & AS & Trisomy 21 & $\begin{array}{l}\text { Fetal nasal bone hypoplasia, abnormal blood flow signals in the right atrium, suspected right coronary } \\
\text { artery-right atrial fistula and hyperechogenic foci in the left ventricle }\end{array}$ & $\begin{array}{l}\text { Induction of } \\
\text { labor }\end{array}$ \\
\hline 14 & AS & Trisomy 21 & $\begin{array}{l}\text { Fetal nasal bone hypoplasia, nuchal translucency thickening, anasarca, endocardial cushion defect and } \\
\text { deepening of notched A-wave on venous catheter }\end{array}$ & $\begin{array}{l}\text { Induction of } \\
\text { labor }\end{array}$ \\
\hline 15 & CS & $47, X Y Y$ & Fetal nasal bone hypoplasia & $\begin{array}{l}\text { Induction of } \\
\text { labor }\end{array}$ \\
\hline 16 & AS & $\begin{array}{l}\text { 46, XY, del(5) } \\
\text { (PI5) }\end{array}$ & Absence of nasal bone & $\begin{array}{l}\text { Induction of } \\
\text { labor }\end{array}$ \\
\hline 17 & AS & Trisomy 18 & $\begin{array}{l}\text { Fetal ventricular septal defect, aorta overriding, mild mitral and tricuspid regurgitation, and nasal bone } \\
\text { hypoplasia }\end{array}$ & $\begin{array}{l}\text { Induction of } \\
\text { labor }\end{array}$ \\
\hline 18 & AS & Trisomy 18 & Artialseptal defect, fetal growth restriction, nasal bone hypoplasia and single umbilical artery & $\begin{array}{l}\text { Induction of } \\
\text { labor }\end{array}$ \\
\hline 19 & AS & Trisomy 18 & $\begin{array}{l}\text { Fetal growth restriction, ventricular septal defect, high pulmonary artery to aorta ratio, nasal bone } \\
\text { hypoplasia and overriding fingers }\end{array}$ & $\begin{array}{l}\text { Induction of } \\
\text { labor }\end{array}$ \\
\hline 20 & CS & $\begin{array}{l}\text { 46, XX, del (4) } \\
(\mathrm{p} \mid 6)\end{array}$ & $\begin{array}{l}\text { Fetal growth restriction, communicating branch of the portal vein, bilateral small kidney and nasal bone } \\
\text { hypoplasia }\end{array}$ & $\begin{array}{l}\text { Induction of } \\
\text { labor }\end{array}$ \\
\hline 21 & AS & $\begin{array}{l}\text { 46, XY, del (4) } \\
(\mathrm{p} \mid 6)\end{array}$ & $\begin{array}{l}\text { Fetal nasal bone hypoplasia, small left ventricle, aortic stenosis, micrognathia, nuchal fold thickening and } \\
\text { single umbilical artery }\end{array}$ & $\begin{array}{l}\text { Induction of } \\
\text { labor }\end{array}$ \\
\hline
\end{tabular}

Abbreviations: AS, amniocentesis; CS, cordocentesis. 
Table 2 Chromosomal Microarray Analysis Detects Copy Number Variations in 10 Fetuses with Nasal Bone Hypoplasia

\begin{tabular}{|c|c|c|c|c|c|c|c|c|}
\hline $\begin{array}{l}\text { Fetus } \\
\text { No. }\end{array}$ & $\begin{array}{l}\text { Invasive } \\
\text { Procedure }\end{array}$ & $\begin{array}{l}\text { Reason for } \\
\text { Referral }\end{array}$ & CMA Detection Results & $\begin{array}{c}\text { Clinical } \\
\text { Significance }\end{array}$ & $\begin{array}{l}\text { Fragment } \\
\text { Size }(\mathrm{Mb})\end{array}$ & $\begin{array}{l}\text { OMIM } \\
\text { Gene } \\
\text { Number }\end{array}$ & Known Syndrome & $\begin{array}{l}\text { Pregnant } \\
\text { Outcome }\end{array}$ \\
\hline 1 & AS & $\begin{array}{l}\text { Nasal bone } \\
\text { hypoplasia }\end{array}$ & $\begin{array}{l}\operatorname{arr}[\text { GRCh37] }|5 q| 3.2 q \mid 3.3 \\
\left(30,386,398 \_32,444,261\right) \times 1\end{array}$ & Pathogenic & 2.0 & 7 & $\begin{array}{c}|5 q| 3.3 \\
\text { microdeletion } \\
\text { syndrome }\end{array}$ & $\begin{array}{l}\text { Induction } \\
\text { of labor }\end{array}$ \\
\hline 2 & AS & $\begin{array}{l}\text { Nasal bone } \\
\text { hypoplasia }\end{array}$ & $\begin{array}{c}\operatorname{arr}[\mathrm{GRCh} 37]|6 p| 2.2 \\
\left(2|, 8| 6,542 \_22,7|0,6| 4\right) \times 1 \\
\text { pat }\end{array}$ & Pathogenic & 0.97 & 4 & $\begin{array}{l}\text { Recurrent } 16 \mathrm{p} / 2.1 \\
\text { microdeletion } \\
\text { (neurodevelopmental } \\
\text { susceptibility locus) }\end{array}$ & $\begin{array}{l}\text { Induction } \\
\text { of labor }\end{array}$ \\
\hline 3 & AS & $\begin{array}{l}\text { Nasal bone } \\
\text { hypoplasia }\end{array}$ & $\begin{array}{c}\operatorname{arr}[G R C h 37] \mid 7 p / 2 \\
\left(14,070,219 \_\mid 5,484,335\right) \times 1\end{array}$ & Pathogenic & 1.4 & 4 & $\begin{array}{l}\text { Hereditary Liability to } \\
\text { Pressure Palsies } \\
\text { (HNPP) }\end{array}$ & $\begin{array}{l}\text { Induction } \\
\text { of labor }\end{array}$ \\
\hline 4 & AS & $\begin{array}{l}\text { Nasal bone } \\
\text { hypoplasia }\end{array}$ & $\begin{array}{c}\operatorname{arr}[\mathrm{GRCh} 37] 15 q \mid 3.3 \\
\left(32,021,609 \_32,444,043\right) \times 3 \\
\text { mat }\end{array}$ & vous & 0.41 & 1 & $\begin{array}{c}|5 q| 3.3 \\
\text { microduplication } \\
\text { syndrome } \\
\text { (neurodevelopmental } \\
\text { susceptibility locus) }\end{array}$ & $\begin{array}{c}\text { Normal } \\
\text { phenotype } \\
\text { after birth }\end{array}$ \\
\hline 5 & AS & $\begin{array}{l}\text { Nasal bone } \\
\text { hypoplasia }\end{array}$ & $\begin{array}{c}\operatorname{arr}[\mathrm{GRCh} 37] \\
|6 \mathrm{p}| 3.13 \mathrm{p} \mid 3.12 \\
\left(\left|1,528,493 \_\right| 2,934,8 \mid 1\right) \times 3\end{array}$ & vous & 1.4 & 9 & - & $\begin{array}{l}\text { Normal } \\
\text { phenotype } \\
\text { after birth }\end{array}$ \\
\hline 6 & AS & $\begin{array}{l}\text { Nasal bone } \\
\text { hypoplasia }\end{array}$ & $\begin{array}{c}\operatorname{arr}[\text { GRCh37] }|5 q| \mid .2 \\
\left(22,770,42 \mid \_23,276,833\right) \times 1 \\
\text { pat }\end{array}$ & vous & 0.50 & 4 & $\begin{array}{l}\text { I5q } \mid 1.2 \text { recurrent } \\
\text { region (BPI-BP2) } \\
\text { (neurodevelopmental } \\
\text { susceptibility locus) }\end{array}$ & $\begin{array}{c}\text { Normal } \\
\text { phenotype } \\
\text { after birth }\end{array}$ \\
\hline 7 & AS & $\begin{array}{l}\text { Nasal bone } \\
\text { hypoplasia }\end{array}$ & $\begin{array}{c}\operatorname{arr}[G R C h 37] 2 p 22.3 \\
\left(34,002,379 \_35,076,738\right) \times 3\end{array}$ & vous & 1.0 & 0 & - & $\begin{array}{c}\text { Normal } \\
\text { phenotype } \\
\text { after birth }\end{array}$ \\
\hline 8 & AS & $\begin{array}{l}\text { Fetal growth } \\
\text { restriction, } \\
\text { ventricular septal } \\
\text { defect, pulmonary } \\
\text { valve stenosis } \\
\text { complicated by } \\
\text { incompetence and } \\
\text { nasal bone hypoplasia }\end{array}$ & $\begin{array}{l}\operatorname{arr}[G R C h 37] \mid 5 q 24.1 \text { q } 24.2 \\
\left(72,965,465 \_75,567,135\right) \times 1\end{array}$ & Pathogenic & 2.6 & 38 & $\begin{array}{l}\text { 15q24 recurrent } \\
\text { microdeletion } \\
\text { syndrome }\end{array}$ & $\begin{array}{l}\text { Induction } \\
\text { of labor }\end{array}$ \\
\hline 9 & AS & $\begin{array}{l}\text { Fetal nasal bone } \\
\text { hypoplasia, biparietal } \\
\text { diameter and } \\
\text { humerus length of } \\
<2 \mathrm{SD} \text {, and } \\
\text { hyperechogenic foci } \\
\text { in the left ventricle }\end{array}$ & $\begin{array}{c}\operatorname{arr}[\mathrm{GRCh} 37] \times \mathrm{X} 21.33 \\
\left(95,227,256 \_95,972,695\right) \times 3 \\
\text { pat }\end{array}$ & vous & 0.7 & 0 & - & $\begin{array}{c}\text { Normal } \\
\text { phenotype } \\
\text { after birth }\end{array}$ \\
\hline 10 & AS & $\begin{array}{c}\text { Fetal nasal bone } \\
\text { hypoplasia and } \\
\text { ventricular septal } \\
\text { defect }\end{array}$ & $\begin{array}{c}\operatorname{arr}[\text { GRCh37] 15q26.1 } \\
\left(90,211,822 \_91,080,606\right) \times 1 \\
\text { pat }\end{array}$ & vous & 0.85 & 13 & - & $\begin{array}{c}\text { Normal } \\
\text { phenotype } \\
\text { after birth }\end{array}$ \\
\hline
\end{tabular}

Abbreviations: AS, amniocentesis; VOUS, variants of uncertain clinical significance. 
Table 3 Comparison of Genomic Abnormality Prevalence Between Fetuses with Nasal Bone Hypoplasia Alone and in Combination with Other Ultrasound Abnormalities

\begin{tabular}{|l|c|c|c|c|}
\hline Group & $\begin{array}{c}\text { Total No. } \\
\text { of Fetuses }\end{array}$ & $\begin{array}{c}\text { Total No. of Fetuses } \\
\text { with Abnormalities }\end{array}$ & $\begin{array}{c}\text { No. of } \\
\text { Chromosomal } \\
\text { Abnormality }\end{array}$ & $\begin{array}{c}\text { No. of Fetuses with } \\
\text { Abnormal CNVs }\end{array}$ \\
\hline Fetuses with nasal bone hypoplasia & 32 & 13 & 6 & 7 \\
\hline $\begin{array}{l}\text { Fetuses with nasal bone hypoplasia and } \\
\text { other ultrasound abnormalities }\end{array}$ & 52 & 18 & 15 & 3 \\
\hline Total & 84 & 31 & 21 & 10 \\
\hline
\end{tabular}

$(P>0.05)$, which is inconsistent with previous reports. $^{24-26}$ It was reported that absence of a nasal nose, complicated with other fetal organ and structural abnormalities increased the risk of chromosomal abnormalities. ${ }^{6,7}$ However, we detected a higher prevalence of genomic abnormality in fetuses with nasal bone hypoplasia alone than those with nasal bone hypoplasia and other ultrasound abnormalities (13/32 vs18/52). This may be because karyotyping analysis alone was employed in previous studies, while both karyotyping and CMA were performed in this study, thereby resulting in a rise in the detection of genomic abnormality; in addition, this variation may be attributed to the study subjects. Nevertheless, the prevalence of chromosomal abnormality was higher in fetuses with nasal bone hypoplasia and other ultrasound abnormalities $(28.85 \%)$ than in those with nasal bone hypoplasia alone (18.75\%), which is in agreement with previous studies. ${ }^{6,7}$

In this study, we detected CNVs in 10 fetuses with nasal bone hypoplasia, and pathogenic CNVs were identified in four fetuses, including 15q13.2q13.3 microdeletion (1 case), 16 p12.2 microdeletion (1 case), 17p12 microdeletion (1 case) and 15q24.1q24.2 microdeletion (1 case). Previous studies have demonstrated that $15 \mathrm{q} 13.2 \mathrm{q} 13.3$ microdeletion may cause $15 \mathrm{q} 13.3$ microdeletion syndrome, which is mainly manifested by developmental retardation, epilepsy, and finger and toe anomalies and minor facial abnormalities. $^{27-29}$ In this study, however, only nasal bone hypoplasia was found in the fetus with 15q13.2q13.3 microdeletions on sonography. A susceptibility locus of neurocognitive impairment has been identified in the region of 16 p12.2 microdeletions, and the frequency of this susceptibility locus is estimated to be less than $1 \%$ in normal populations. ${ }^{30}$ In the ClinGen database, the haploinsufficiency score of the recurrent $16 \mathrm{p} 12.2$ microdeletion is 2 , while the overall penetrance is approximately $12 \%{ }^{31}$ Patients with 16p12.2 microdeletions have diverse clinical manifestations, which mainly include developmental retardation, mild to moderate intellectual disturbance, congenital heart defects and epilepsy. ${ }^{32}$ However, ultrasound examinations displayed nasal bone hypoplasia alone in the fetus with $16 \mathrm{p} 12.2$ microdeletions. $17 \mathrm{p} 12$ microdeletion is reported to link with hereditary neuropathy with liability to pressure palsies (HNPP). ${ }^{33}$ To date, the penetrance of $17 \mathrm{p} 12$ microdeletions remains unknown, and many patients carrying $17 \mathrm{p} 12$ microdeletions present few and even no clinical symptoms; in addition, approximately $80 \%$ of deletions of the PMP22 gene on chromosome $17 \mathrm{p} 12$ regions are estimated to be inherited from parents, where haploinsufficiency effect is observed with a score of $3 ;^{34}$ however, only nasal bone hypoplasia was seen in the fetus with 17 p12 microdeletions. 15q24.1q24.2 Microdeletion has been identified as a pathogenic factor of $15 \mathrm{q} 24$ microdeletion syndrome, which manifests as feeding intolerance, eye abnormality, widening of neck, nasal bone hypoplasia, muscle hypotonia, attention-deficit/hyperactivity disorder and autism. ${ }^{35}$ In this study, ultrasound displayed fetal growth restriction, ventricular septal defect, pulmonary valve stenosis complicated by incompetence and nasal bone hypoplasia in the fetus with $15 \mathrm{q} 24.1 \mathrm{q} 24.2$ microdeletions. These data indicate that chromosome karyotyping is likely to lead to missing diagnosis and misdiagnosis of genomic microstructural abnormality in fetuses with nasal bone hypoplasia detected by ultrasound. Our data suggest that CMA has an extensive range of indications to detect chromosomal microstructural abnormalities and shows a powerful value in prenatal diagnosis.

Nevertheless, there is a difficulty in the interpretation of the clinical significance of CMA detection results, notably in the interpretation of VOUS, and the huge rise in CMA detections interpretation will inevitably increase the burden of validations. Previous studies have shown a $1.1 \%$ to $6 \%$ detection of VOUS by CMA. ${ }^{36-38}$ In this study, CMA detected in VOUS in 6 out of 84 fetuses with nasal bone hypoplasia, and the 
VOUS prevalence (7.14\%) was higher than previous reports. ${ }^{36-38}$ Pedigree analysis confirmed that four cases were $\mathrm{h}$ inherited from healthy parents. In cases with VOUS, two cases were detected with neural susceptibility sites, which contained $15 \mathrm{q} 13.3$ microduplication and $15 q 11.2$ recurrent region. If the CNVs were verified to be inherited, it would reduce the psychological burden of pregnant women, and pregnant women will be more willing to choose to keep the fetus. Recently, nextgeneration sequencing has been employed as a novel tool for genetic testing of single-gene mutations and CNVs, which may provide a more comprehensive prenatal genetic diagnosis for fetuses with nasal bone hypoplasia, and provide insights into a better assessment of fetal prognosis. ${ }^{39-41}$

Prenatal genetic testing determines the decision to terminate pregnancy. ${ }^{42}$ In the present study, 84 fetuses with nasal bone hypoplasia were all successfully followed up, and pregnancy termination was performed in 21 fetuses detected with chromosomal abnormality and 4 fetuses detected with pathogenic CNVs, while the pregnancy continued in other 6 fetuses detected with VOUS, and these babies all had normal clinical phenotypes after birth. It is therefore considered that CMA may provide valuable data for the accurate assessment of fetal prognosis and risk of disease recurrence and the decision of pregnancy continuation during the prenatal clinical counseling. ${ }^{22,43-45}$

The present study has some limitations. First, this retrospective analysis was performed in a cohort including 84 fetuses with nasal bone hypoplasia recruited from a single center, and further multicenter studies recruiting more fetuses are needed. Second, not all cases with VOUS were given additional pedigree analyses, which is ineffective to provide better guidance for genetic counseling.

In summary, the results of the present study demonstrate that CMA increases the detection of CNVs in fetuses with nasal bone hypoplasia relative to conventional chromosome karyotyping. It is considered that CMA is a powerful tool used for prenatal diagnosis in fetuses with nasal bone hypoplasia.

\section{Funding}

This study was funded by the grants from the Fujian Provincial Natural Science Foundation (2017J01238).

\section{Disclosure}

The authors declare no conflict of interests.

\section{References}

1. Marsál K. Role of Doppler sonography in fetal/maternal medicine. Curr Opin Obstet Gynecol. 1994;6(1):36-44. doi:10.1097/00001703199402000-00006

2. Van den Hof MC, Wilson RD, Diagnostic Imaging Committee. Society of Obstetricians and Gynaecologists of Canada; Genetics Committee, Society of Obstetricians and Gynaecologists of Canada. Fetal soft markers in obstetric ultrasound. J Obstet Gynaecol Can. 2005;27(6):592-636. doi:10.1016/s1701-2163(16)30720-4

3. Getz L, Kirkengen AL. Ultrasound screening in pregnancy: advancing technology, soft markers for fetal chromosomal aberrations, and unacknowledged ethical dilemmas. Soc Sci Med. 2003;56 (10):2045-2057. doi:10.1016/S0277-9536(02)00200-9

4. Wong SF, Choi H, Ho LC. Nasal bone hypoplasia: is it a common finding amongst chromosomally normal fetuses of southern Chinese women? Gynecol Obstet Invest. 2003;56(2):99-101. doi:10.1159/000072994

5. Rao R, Platt LD. Ultrasound screening: status of markers and efficacy of screening for structural abnormalities. SeminPerinatol. 2016;40 (1):67-78.

6. Sciarrone A, Bastonero S, Campogrande M. Ultrasound evaluation of fetal nasal bone at 11 to 14 weeks in a consecutive series of 1906 fetuses. Prenat Diagn. 2003;23(10):784-787. doi:10.1002/pd.694

7. Cicero S, Longo D, Rembouskos G, Sacchini C, Nicolaides KH. Absent nasal bone at 11-14 weeks of gestation and chromosomal defects. Ultrasound Obstet Gynecol. 2003;22(1):31-35. doi:10.1002/uog.170

8. Odibo AO, Sehdev HM, Dunn L, McDonald R, Macones GA. The association between fetal nasal bone hypoplasia and aneuploidy. Obstet Gynecol. 2004;104(6):1229-1233. doi:10.1097/01. AOG.0000148848.49752.37

9. Odibo AO, Sehdev HM, Sproat L, et al. Evaluating the efficiency of using second-trimester nasal bone hypoplasia as a single or a combined marker for fetal aneuploidy. $J$ Ultrasound Med. 2006;25(4):437-441. doi:10.7863/jum.2006.25.4.437

10. Cusick W, Provenzano J, Sullivan CA, Gallousis FM, Rodis JF. Fetal nasal bone length in euploid and aneuploid fetuses between 11 and 20 weeks' gestation: a prospective study. J Ultrasound Med. 2004;23 (10):1327-1333. doi:10.7863/jum.2004.23.10.1327

11. Węgrzyn P, Czuba B, Serafin D, et al. Nasal bone in screening for T21 at 11-13 + 6 weeks of gestation - a multicenter study. Ginekol Pol. 2016;87(11):751-754. doi:10.5603/GP.2016.0082

12. Papasozomenou P, Athanasiadis AP, Zafrakas M, et al. Screening performance of different methods defining fetal nasal bone hypoplasia as a single and combined marker for the detection of trisomy 21 in the second trimester. J Matern Fetal Neonatal Med. 2016;29 (20):3368-3373. doi:10.3109/14767058.2015.1127344

13. Yu J, Sun Y, Hu J, Qian Y, Luo Y, Dong M.Single nucleotide polymorphism microarray in prenatal diagnosis of fetuses with absent nasal bone. Zhejiang Da Xиe Xue Bao Yi Xue Ban. 2019;48(4):414-419.

14. Gu YZ, Nisbet DL, Reidy KL, Palma-Dias R. Diagnostic value of chromosomal microarray in fetuses with isolated hypoplastic nasal bone. Ultrasound Obstet Gynecol. 2019;54(2):284. doi:10.1002/ uog. 20385

15. Lin CZ, Qi BR, Hu JS, Huang XQ. A fetus with Kabuki syndrome 2 detected by chromosomal microarray analysis. Int J Clin Exp Pathol. 2020;13(2):302-306.

16. Kearney HM, Thorland EC, Brown KK, Quintero-Rivera F, South ST. Working Group of the American College of Medical Genetics Laboratory Quality Assurance Committee. American College of Medical Genetics standards and guidelines for interpretation and reporting of postnatal constitutional copy number variants. Genet Med. 2011;13(7):680-685. doi:10.1097/GIM.0b013e3182217a3a

17. Wojda KM, Moczulska H, Sieroszewski PJ. The absence of fetal nasal bones in ultrasound examination between $11+0$ and $13+6$ weeks of gestation versus the occurrence of trisomies 21, 18, and 13 . Ginekol Pol. 2019;90(10):604-606. doi:10.5603/GP.2019.0104 
18. Bromley B, Lieberman E, Shipp TD, Benacerraf BR. Fetal nose bone length: a marker for Down syndrome in the second trimester. J Ultrasound Med. 2002;21(12):1387-1394. doi:10.7863/ jum.2002.21.12.1387

19. Sonek JD, Cicero S, Neiger R, Nicolaides KH. Nasal bone assessment in prenatal screening for trisomy 21. Am J Obstet Gynecol. 2006;195(5):1219-1230. doi:10.1016/j.ajog.2005.11.042

20. Treff NR, Levy B, Su J, Northrop LE, Tao X, Scott RT Jr. SNP microarray-based 24 chromosome aneuploidy screening is significantly more consistent than FISH. Mol Hum Reprod. 2010;16 (8):583-589. doi:10.1093/molehr/gaq039

21. Hall GK, Mackie FL, Hamilton S, et al. Chromosomal microarray analysis allows prenatal detection of low level mosaic autosomal aneuploidy. Prenat Diagn. 2014;34(5):505-507. doi:10.1002/pd.4333

22. Levy B, Wapner R. Prenatal diagnosis by chromosomal microarray analysis. Fertil Steril. 2018;109(2):201-212. doi:10.1016/j. fertnstert.2018.01.005

23. Wapner RJ, Martin CL, Levy B, et al. Chromosomal microarray versus karyotyping for prenatal diagnosis. N Engl J Med. 2012;367 (23):2175-2184. doi:10.1056/NEJMoa1203382

24. Ting YH, Lao TT, Lau TK, Chung MK, Leung TY. Isolated absent or hypoplastic nasal bone in the second trimester fetus: is amniocentesis necessary? J Matern Fetal Neonatal Med. 2011;24(4):555-558. doi:10.3109/14767058.2010.487140

25. Lu J, Zhong XH, Li LF, et al.The role of isolated absent nasal bone in the screening of Down syndrome in the second and third trimester. Chin J Birth Health Hered. 2015;23(4):54-56, 40.

26. Zhao Y, Sun QM, Fu Y, Dai WS, Lin XJ, Wu J. Analysis on genetic significance of fetal nasal bone hypoplasia during the second and the third trimesters of pregnancy. Matern Child Health Care Chin. 2016;31(23):5098-5101.

27. Ben-Shachar S, Lanpher B, German JR, et al. Microdeletion 15q13.3: a locus with incomplete penetrance for autism, mental retardation, and psychiatric disorders. J Med Genet. 2009;46(6):382-388. doi:10.1136/jmg.2008.064378

28. Ziats MN, Goin-Kochel RP, Berry LN, et al. The complex behavioral phenotype of 15q13.3 microdeletion syndrome. Genet Med. 2016;18 (11):1111-1118. doi:10.1038/gim.2016.9

29. Hassfurther A, Komini E, Fischer J, Leipoldt M. Clinical and genetic heterogeneity of the 15q13.3 Microdeletion Syndrome. Mol Syndromol. 2016;6(5):222-228. doi:10.1159/000443343

30. Pizzo L, Andrieux J, Amor DJ, Girirajan S. Clinical utility gene card for: 16p12.2 microdeletion. Eur J Hum Genet. 2017;25(2):271. doi:10.1038/ejhg.2016.158

31. Rosenfeld JA, Coe BP, Eichler EE, Cuckle H, Shaffer LG. Estimates of penetrance for recurrent pathogenic copy-number variations. Genet Med. 2013;15(6):478-481. doi:10.1038/gim.2012.164

32. Kirov G, Rees E, Walters JT, et al. The penetrance of copy number variations for schizophrenia and developmental delay. Biol Psychiatry. 2014;75(5):378-385. doi:10.1016/j.biopsych.2013.07.022
33. Attarian S, Fatehi F, Rajabally YA, Pareyson D. Hereditary neuropathy with liability to pressure palsies. J Neurol. 2020;267 (8):2198-2206. doi:10.1007/s00415-019-09319-8

34. Lefour S, Gallouedec G, Magy L. Comparison of clinical and electrophysiological features of patients with hereditary neuropathy with liability to pressure palsies with or without pain. $J$ Neurol Sci. 2020;409:116629. doi:10.1016/j.jns.2019.116629

35. Magoulas PL, El-Hattab AW. Chromosome 15q24 microdeletion syndrome. Orphanet J Rare Dis. 2012;7:2. doi:10.1186/17501172-7-2

36. Breman A, Pursley AN, Hixson P, et al. Prenatal chromosomal microarray analysis in a diagnostic laboratory; experience with $>1000$ cases and review of the literature. Prenat Diagn. 2012;32 (4):351-361. doi:10.1002/pd.3861

37. Hillman SC, Pretlove S, Coomarasamy A, et al. Additional information from array comparative genomic hybridization technology over conventional karyotyping in prenatal diagnosis: a systematic review and meta-analysis. Ultrasound Obstet Gynecol. 2011;37(1):6-14. doi:10.1002/uog.7754

38. Faas BH, van der Burgt I, Kooper AJ, et al. Identification of clinically significant, submicroscopic chromosome alterations and UPD in fetuses with ultrasound anomalies using genome-wide 250k SNP array analysis. J Med Genet. 2010;47(9):586-594. doi:10.1136/ jmg.2009.075853

39. Shen W, Szankasi P, Durtschi J, Kelley TW, Xu X. Genome-wide copy number variation detection using NGS: data analysis and interpretation. Methods Mol Biol. 2019;1908:113-124.

40. Ellingford JM, Campbell C, Barton S, et al. Validation of copy number variation analysis for next-generation sequencing diagnostics. Eur J Hum Genet. 2017;25(6):719-724. doi:10.1038/ ejhg.2017.42

41. Yao R, Yu T, Qing Y, Wang J, Shen Y. Evaluation of copy number variant detection from panel-based next-generation sequencing data. Mol Genet Genomic Med. 2019;7(1):e00513. doi:10.1002/mgg3.513

42. Dukhovny S, Norton ME. What are the goals of prenatal genetic testing? Semin Perinatol. 2018;42(5):270-274. doi:10.1053/j. semperi.2018.07.002

43. Oneda B, Rauch A. Microarrays in prenatal diagnosis. Best Pract Res Clin Obstet Gynaecol. 2017;42:53-63. doi:10.1016/j. bpobgyn.2017.01.003

44. Stosic M, Levy B, Wapner R. The use of chromosomal microarray Analysis in prenatal diagnosis. Obstet Gynecol Clin North Am. 2018;45(1):55-68. doi:10.1016/j.ogc.2017.10.002

45. Lo JO, Shaffer BL, Feist CD, Caughey AB. Chromosomal microarray analysis and prenatal diagnosis. Obstet Gynecol Surv. 2014;69 (10):613-621. doi:10.1097/OGX.0000000000000119
Risk Management and Healthcare Policy

\section{Publish your work in this journal}

Risk Management and Healthcare Policy is an international, peerreviewed, open access journal focusing on all aspects of public health, policy, and preventative measures to promote good health and improve morbidity and mortality in the population. The journal welcomes submitted papers covering original research, basic science, clinical \& epidemiological studies, reviews and evaluations, guidelines, expert opinion and commentary, case reports and extended reports. The manuscript management system is completely online and includes a very quick and fair peer-review system, which is all easy to use. Visit http://www.dovepress.com/testimonials.php to read real quotes from published authors. 